\title{
Changing Information Needs of Social Impact of Nuclear Power Plant Siting
}

\author{
-Through a Comparison Before and After the Fukushima \\ Daiichi Nuclear Power Plant Accident-
}

\author{
Takako KASHIWA $^{1, *}$ and Yoshimi KAWAMOTO ${ }^{1}$ \\ ${ }^{1}$ Nuclear Power and Energy Safety Engineering, University of Fukui, 3-9-1 Bunkyo, Fukui-shi, Fukui 910-8507, Japan
}

\begin{abstract}
In the light of the Fukushima Daiichi Nuclear Power Plant Accident, we need to consider a symbiosis method based on the diminution of the nuclear power industry. To find a region that does not excessively depend on the nuclear power industry, it is necessary to examine and discuss the social impact of nuclear-related industries. In this study, we compared people's changing information needs of social impact before and after the Fukushima Daiichi Nuclear Power Plant Accident. It was found that the need for information increased after the accident. In particular, there were three research areas where the need for information increased: the consideration of building nuclear power plants, the influence of harmful rumors on the region, and influence on the nuclear power industry. Next, attempts were made to understand whether there is a difference between information needs of social impact by attributes, such as age, sex and knowledge of nuclear power. The information needs of the following categories of people increased after the accident: people aged between 10 and 50 years, women, people who do not have a clear opinion about the use of a nuclear power plant, and people who do not have any knowledge of nuclear power.
\end{abstract}

KEYWORDS: nuclear power plant siting, social impact, information needs, opinion survey

\section{Introduction}

Potential risks and economic impacts of nuclear power are related not only to the municipality where the nuclear power plant is located but also the entire society. Therefore, the relation between a nuclear power plant and the municipality where the power plant is sited has increasingly been reported on by the media after the Fukushima Daiichi Nuclear Power Plant Accident (hereinafter referred to as "the accident"), and we are now required to consider how to live with nuclear power as one of our future directions, while assuming that the size of the nuclear industry will diminish. As one of the options, in order for local communities not to overly depend on the nuclear industry, unlike the current situation where the nuclear industry is the main industry of a region, we will have to take a multi-phased approach to recognize and become interested

\footnotetext{
* Corresponding author, E-mail: pabrofukenspring@yahoo.co.jp

DOI : 10.15669/fukushimainsights. Vol.4.188

(C) 2021 Atomic Energy Society of Japan. All rights reserved.

Originally published in Transactions of the Atomic Energy Society of Japan (ISSN 1347-2879), Vol. 12, No. 2, p. 128-137

(2013) in Japanese. (Japanese version accepted: January 9, 2013)
} 
in the social impacts of the location of a nuclear power plant on everyday life and industries, be aware of questions, develop our own opinions, and understand a diverse range of values ${ }^{\mathrm{a}}$.

Looking at the information on nuclear power plants that has been provided by the government and power companies, their focus was on safety measures and operations. Also, previous studies ${ }^{2-4)}$ focusing on nuclear power information were based on the idea of understanding what information citizens need, from a list of items including the nuclear power generation mechanisms and safety measures, technical and engineering information on radiation, and providing support for risk communication. However, these previous studies do not examine whether people are aware of and interested in information that presents the social impacts of nuclear power plant siting. Therefore, to explore these, we need to understand what information on social impacts people feel they need.

According to a paper by Tsujikawa ${ }^{5)}$ investigating how people's perceptions of the need for, and apprehension towards, nuclear power influence their attitudes to nuclear power, the more people are aware of the need, the more they are likely to be motivated to collect and examine information on nuclear power.

Tsujikawa also mentioned that the fact that people recognize the importance of nuclear power. For example, the fact that they understand that nuclear energy supports our power supply and has become a public benefit indicates that people recognize that nuclear energy is closely related to the smooth functioning of modern society, and that those who recognize its importance have, at least to a certain degree, a detailed knowledge of nuclear power. This leads us to assume that those who are relatively favorably disposed towards and knowledgeable about nuclear energy are actively trying to understand the social impacts that nuclear power has. For example, what role nuclear power plays in modern society. On the other hand, those who do not take a definite stance on and are not interested in nuclear energy may be less interested in any information about the social impacts that nuclear power has, or any overall information on nuclear energy.

In this study, we attempt to understand the changes in people's perceived information needs regarding the social impact that nuclear power plant siting has by examining people's awareness and attitudes both before and after the accident. Then, to find out whether people have different information needs concerning the social influences that nuclear power has, depending on their general interest in nuclear power, we endeavor to understand the changes in information needs before and after the accident by focusing on "people's attitudes toward nuclear power," "those who are less interested in nuclear power," and "those who have relatively less knowledge on nuclear power." Lastly, we will perform a detailed analysis to find out what specific information people are interested in through a qualitative evaluation using open-ended questions.

\section{Survey Overview}

After the accident, it became clear that the impacts of a nuclear accident do not affect only the immediate area where the power plant is located but also involve wider areas. Moreover, economic benefits, including the subsidy on "Electric Power Development based on the Three Laws" also affect not only the immediate area but also the entire prefecture where the plant is located.

\footnotetext{
a According to "Model of knowledge cultivation activity" proposed by Kimura et al. ${ }^{1)}$, there are five stages, namely, "Recognition," "Showing interest," "Having doubts," "Forming one's own opinion," "Knowing various values" and these form the knowledge base for making individual judgments.
} 
In order to explore new ways to live with nuclear power, we think it necessary to examine the local community from a wide perspective. In this study, setting the study target as Fukui Prefecture, where the power plant is located, we would like to study Fukui City, which is the center of the economy and government of Fukui Prefecture.

The authors conducted interview surveys between 2009 and 2010 of local residents of the area where the nuclear power plant is located to investigate the impact of the plant siting on their living environment ${ }^{\mathrm{b}}$. We categorized the social impacts of the nuclear power plant's siting into 10 items by referring to the opinions acquired through the survey, and formulated survey items. Then, we created a leaflet including this content in questionnaire form. In the leaflet, we provided simple examples of the social impacts of the nuclear power plant and asked whether the respondents had wanted to hear about the information contained in the questionnaire before the accident, or only now want to hear about this information as a result of the accident. Tables 1 and $\mathbf{2}$ show the content of the leaflet and the survey overview, respectively.

As the response collection rate was low, we would like to provide the general features of collected data. According to the national census in 2010, the total population of Fukui City was 266,796. The gender composition was: Male 48\%; Female 52\%. Age composition: teens $11 \%$, 20 's $12 \%$, 30's $16 \%$, 40's $15 \%$, 50's $17 \%$, 60's $14 \%$, 70's and older $15 \%$. In this study, the respondents consisted of $52 \%$ males and $45 \%$ females, which shows a little bias towards males. Also, participants included $1 \%$ teens, 6\% 20's, 10\% 30's, 17\% 40's, 19\% 50's, $28 \% 60$ 's, and $15 \% 70$ 's and older, which shows a lack of response from the younger generation between teens and 30's and is biased toward the middle-aged and old-age groups. Also, for the question that asked whether the respondents are interested in nuclear power, $64 \%$ of them, more than half, answered they were "Interested" or "A little interested" since before the Fukushima Daiichi Nuclear Power Plant Accident, showing that many respondents were interested in nuclear power plants before the accident. It is assumed that this shows those who are not interested in the study theme did not answer the questions in the first place. When we have a bias in the sample, in general, it needs to be corrected. However, if it is corrected, the number of samples will decline, and we won't be able to reflect many opinions. Also, some responses questioned the format, such as "how was it before the accident," which ask how their awareness or attitudes changed after the accident. Therefore, such results are not fully valid comparisons before and after the accident.

\section{Trends of Information Needs}

\section{Overall Trends}

We made comparisons before and after the accident to understand the changes in information needs pertaining to the social impact of nuclear power siting. In the survey, respondents were asked to select their answer from four choices: "Would like to hear," "Would somewhat like to hear," "Would not particularly like to hear" and "Would not like to hear" — to 10 inquiry items concerning the social impact (hereinafter referred to as "items") of nuclear power plant siting before and after the accident. Example questions are provided in Figure 1, and answers

\footnotetext{
${ }^{\mathrm{b}}$ For the Hearing Survey in 2010, we selected 18 areas of concern (Nature, Sewage, Communication and Exchange, Children, Roads, Facilities, Fishery, Medicine, Tradition, Shopping, Welfare, Disasters, Emergency, Employment, Tourism, Transfer, Traffic, Agriculture) that are considered relevant to daily life in the area where a nuclear power plant is located. For the Hearing Survey in 2009, we selected 8 items (Human Resources, Culture, Communication and Exchange, Education, Nature, Primary Industry, Secondary Industry, Tertiary Industry) that are considered to be regional resources.
} 
Table 1 Leaflet contents

Item

(1) Awareness of and attitudes to nuclear power

(2) Influence of harmful rumors

(3) Relationship with the power company

(4) Impacts on activities

(5) Changes in scenery

(6) Changes in infrastructure development

(7) Opinions about energy education

\section{(8) Impacts on
industries}

\section{(9) Opinions about} PR activities about the region cultural and sports

mar

\author{
Examples of residents' opinions
}

I am not concerned about nuclear power as long as the power plant is safely operated/I am not concerned about nuclear power as long as we understand the risks and management structure of it/We have less reason to remonstrate against the plant due to the expansion of employment and economic benefits/We still have some concern about the power plant.

The number of tourists will decrease when an accident happens/The media were annoying when the accident happened/The media were apparently trying to pick up only negative comments and ignore positive opinions/Local people do not recognize dangerous impacts as much as people from outside do/There are harmful rumors that agricultural products and fish are contaminated by radiation.

We have relationships with nuclear-related workers through events and the obon dance festival in the Nuclear PR Center/We have no contact with management company and power company in everyday life/By actively associating with nuclear-related workers living in the neighborhood, we can develop relationships with each other and build trust in the company through them/Although we used to actively associate with the power company and residents, now we have fewer opportunities.

More people participate in the festival, and the size has become larger/The size of the festival has become larger, but we have less autonomy/As people can exhibit their artworks at the nuclear power-related facility (PR Center), their financial burden has been reduced and are more motivated, which promotes cultural activities/We have organized an official art organization through association with various people from outside/As some nuclear-related male employees have become coaches of sport teams such as junior sports teams, sports activities have become more active.

The power plant will not damage the natural environment/The scenery is beautiful around here, and I think the natural environment is preserved/I don't feel that nature is considered important in daily life. If a new plant is constructed, some aspects of nature will be damaged and roads will be redeveloped. This will markedly change the scenery.

It is good that the sewage system and roads have been well developed. Roads used to be narrow, and when it snowed, we had to go to school and work by walking along the beach. New roads have made our lives very easy/Although sewage system and roads have been improved in the early stage, I think they would have been improved one day anyway even if the power plant was not constructed/Community centers have been renovated to a better standard, and more public facilities are provided/There are few facilities really needed by the citizens because they may not have been built based on actual community requirements/I don't think the power company provides us something special because they have built their power plant in our area.

I think it is good to provide energy education at an early age/I want energy education that contributes to human resources development/We are not familiar with the research center as part of our daily life, and we have no idea what is held there/I think it will be great if local human resource development measures are provided and research is performed in collaboration with local companies in the research center.

Employment by the power plant-related companies has increased/Not only tourists but also temporary regular inspection workers use Minshuku guest houses/Fewer people inherit their family fishing businesses because more people go to work outside/Construction businesses receive more orders for construction works/More restaurants and supermarkets have been constructed and made our life more convenient/The industry of the area has basically become dependent on the nuclear power plant.

I know about the nuclear-related PR magazine, but I have never read it carefully/Information on nuclearrelated accidents is provided by media such as TV sooner than in the PR magazine/I would like not only the people in the area where the power plant is located but also energy consumption areas to gain an understanding of nuclear power. Also, I want the power company to not only try to tell us about the safety of nuclear power but also allow us to have positive discussions.

(10) Technology Research on jellyfish guiding techniques and processing technologies/Made Heshiko production more collaboration and efficient by controlling temperature and pressure/Development of work clothes with well-balanced water development resistance and air permeability.

*Examples of residents' opinions on the leaflet are a representation of some responses to the interview survey, and only 3 to 5 examples (100 to 200 characters) are provided for each item.

\section{are provided in Figure 2.}

Of the 10 items, the one that the largest number of people answered "Would like to hear" was "Impact on industries" with $14 \%$ and the smallest number was "Impacts on cultural and sport activities" with $5 \%$ before the accident. When we look at the overall trend, only about $10 \%$ of respondents answered, "Would like to hear," and there was no item where more than half of respondents answered either "Would like to hear" or "Would somewhat like to hear."

As for the results after the accident, more respondents answered they "Would like to hear" 
Table 2 Survey overview

\begin{tabular}{ll}
\hline Target audience & Fukui citizens \\
Survey period & May to June 2011 \\
& Questionnaire survey \\
Area sampling \\
(Randomly selected from the index of the central city of Fukui City in Zenrin Residential \\
Map of Fukui City, Fukui Prefecture \\
Survey method \\
Distribution: Posting/Collection: Postal mail \\
4istribution/ \\
4,000 \\
(Two forms were distributed to 2,000 households) \\
3umber of distributions & 1. Attributes (Age/Gender/Occupation) \\
2. Interest in social impact of nuclear power plant siting (the following 10 items) & (1) Awareness of and attitudes to nuclear power \\
(2) Influence of harmful rumors about the region & (3) Relationship with the power company \\
(4) Impacts on cultural and sports activities & (5) Changes in scenery \\
(6) Changes in infrastructure development & (7) Opinions about energy education \\
(8) Impact on industries \\
(9) Opinions about PR activities \\
(10) Technology collaboration and development \\
3. Questions for residents who live in the area where the nuclear power plant is located \\
4. Interest in the nuclear power plant, and energy and environmental issues \\
5. Knowledge of nuclear power \\
6. How to acquire information on nuclear power and energy issues \\
7. Image of nuclear power \\
8. Attitudes to nuclear power
\end{tabular}

*In Questions 2, 4, 5, and 8, comparisons were made before and after the Fukushima Daiichi Nuclear Power Plants Accident in the same questionnaire form.

Questions (Sample) Influence of harmful rumors about the region

Question 1-1. Present

\begin{tabular}{|l|l|l|l|l|}
\hline $\begin{array}{l}\text { Would like to } \\
\text { hear }\end{array}$ & $\begin{array}{l}\text { Would } \\
\text { somewhat like } \\
\text { to hear }\end{array}$ & $\begin{array}{l}\text { Would } \\
\text { particularly } \\
\text { want to hear }\end{array}$ & $\begin{array}{l}\text { Would not want } \\
\text { to hear }\end{array}$ \\
\hline
\end{tabular}

What did you think about it before the accident?

\begin{tabular}{|l|l|l|l|}
\hline Wanted to hear & $\begin{array}{l}\text { Somewhat } \\
\text { wanted to hear }\end{array}$ & $\begin{array}{l}\text { Didn't } \\
\text { particularly } \\
\text { want to hear }\end{array}$ & $\begin{array}{l}\text { Didn't want to } \\
\text { hear }\end{array}$ \\
\hline
\end{tabular}

Question 1-2. This question is for those who answered, "Would like to hear" (Wanted to hear) and "Would somewhat like to hear" (Somewhat wanted to hear) now and before the accident. Why do/did you want to hear about it?
(1) It is interesting because we have hardly had the opportunity to hear about it.
(2) It is easy to understand the feelings and lives of the residents who live in the area where a power plant is located.
(3) It is helpful to reduce harmful rumors about the region.
(4) Others ( )

Question 1-3. Provide your questions on "Influence of harmful rumors about the region," if you have any.

Figure 1 Sample questions 

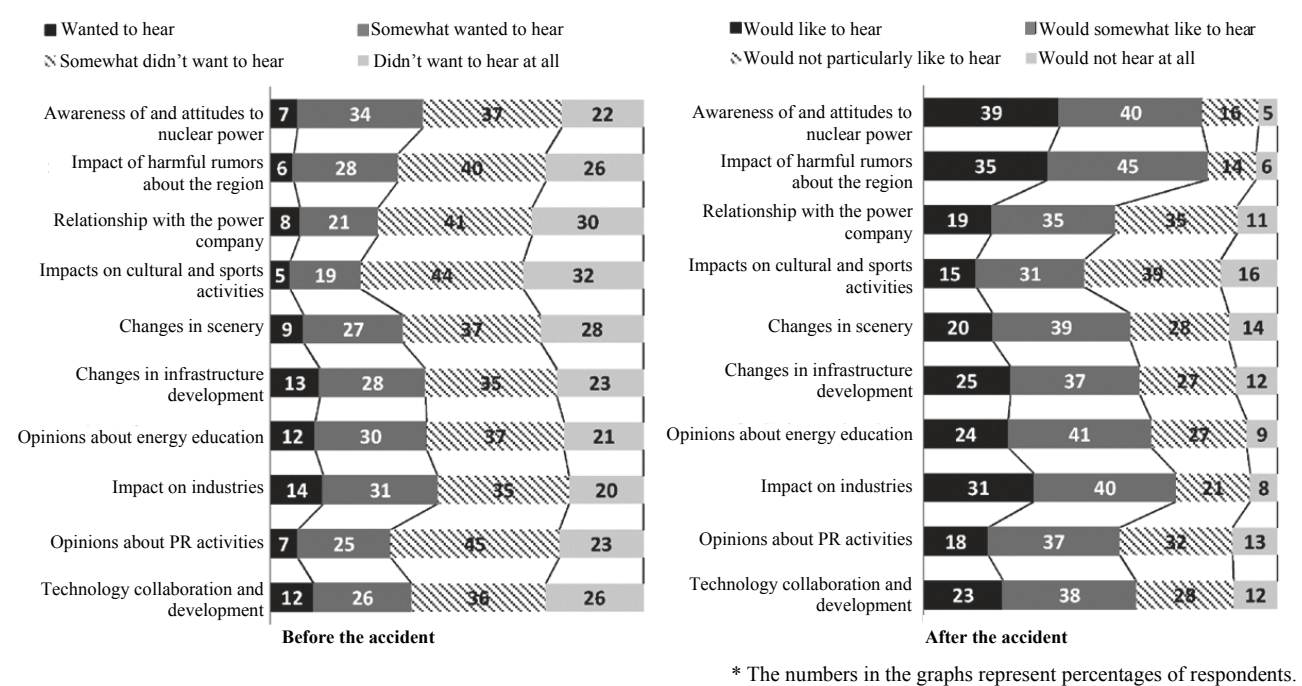

Figure 2 Proportions of interest by item before and after the Fukushima Daiichi Nuclear Power Plant Accident

for the question item on "Awareness of and attitudes to nuclear power," "Influence of harmful rumors about the region," and "Impact on industries," which shows that more respondents are willing to hear about social impact than before.

Also, although there was no item where more than half of respondents answered "Would like to hear" or "Would somewhat like to hear" before the accident, over half of the respondents answered "Would like to hear" or "Would somewhat like to hear" for 9 items out of 10 after the accident. This shows that the need for information on the social impact of nuclear power plant siting has increased after the accident. Also, before the accident, the information needs for "Impact on industries" were the highest.

However, more respondents answered "Would like to hear" about "Awareness of nuclear power," "Influence of harmful rumors about the region," "Impact on industries" and more than $70 \%$ of respondents answered either "Would like to hear" or "Would somewhat like to hear" after the accident. This means that more people showed their interest in more items after the accident.

Next, we scored respondents' answers to quantify the need for each item. Four points were given to "Would like to hear," 3 points to "Would somewhat like to hear," 2 points to "Would not particularly like to hear," and 1 point to "Would not like to hear." Note that the score does not indicate an absolute evaluation but rather a relative evaluation. The results are shown in Table 3.

The items where average scores became highest after the accident were three: "Awareness of and attitudes to nuclear power," "Influence of harmful rumors about the region," and "Impact on industries." Among them, the average score gap of "Influence of harmful rumors about the region" before and after the accident was 1 , which is the highest, and we can say that this is an item where the need has become higher after the accident. Also, although "Impact on industries" was the item with the highest need at the average score of 2.40 before the accident, the item with the highest average score was "Awareness of and attitudes to nuclear power" after the accident, so the item that draws people's interest has changed after the accident. Because of the increasing general interest in nuclear power after the accident, the need for information on "Awareness of and attitudes to nuclear power" also increased. Furthermore, after the accident, 
Table 3 Average scores before and after the accident

\begin{tabular}{|c|c|c|c|c|c|}
\hline Item & Before & After & $\begin{array}{c}\text { Difference } \\
\text { between } \\
\text { average scores }\end{array}$ & $\begin{array}{l}\text { Standard } \\
\text { deviation } \\
\text { (Before) }\end{array}$ & $\begin{array}{c}\text { Standard } \\
\text { deviation } \\
\text { (After) }\end{array}$ \\
\hline $\begin{array}{l}\text { Awareness of and attitudes to } \\
\text { nuclear power }\end{array}$ & 2.30 & 3.10 & 0.80 & 0.88 & 0.86 \\
\hline $\begin{array}{l}\text { Influence of harmful rumors about } \\
\text { the region }\end{array}$ & 2.10 & 3.10 & 1.00 & 0.88 & 0.85 \\
\hline $\begin{array}{l}\text { Relationship with the power } \\
\text { company }\end{array}$ & 2.10 & 2.60 & 0.50 & 0.91 & 0.92 \\
\hline $\begin{array}{l}\text { Impacts on cultural and sports } \\
\text { activities }\end{array}$ & 2.00 & 2.40 & 0.40 & 0.85 & 0.93 \\
\hline Changes in scenery & 2.20 & 2.60 & 0.40 & 0.93 & 0.95 \\
\hline $\begin{array}{l}\text { Changes in infrastructure } \\
\text { development }\end{array}$ & 2.30 & 2.70 & 0.40 & 0.97 & 0.96 \\
\hline Opinions about energy education & 2.30 & 2.80 & 0.50 & 0.94 & 0.90 \\
\hline Impact on industries & 2.40 & 3.00 & 0.60 & 0.96 & 0.91 \\
\hline Opinions about PR activities & 2.20 & 2.60 & 0.40 & 0.86 & 0.93 \\
\hline $\begin{array}{l}\text { Technology collaboration and } \\
\text { development }\end{array}$ & 2.20 & 2.70 & 0.50 & 0.97 & 0.95 \\
\hline Total average & 2.21 & 2.77 & 0.57 & & \\
\hline
\end{tabular}

the impact of restrictions and harmful rumors related to food products on tourism, scheduled power outages, and other direct impacts on the local people's lives probably increased the need for information in an attempt to gain insight into economic consequences, such as the impact of the harmful rumors on the local area or those on the industry of the area.

\section{Trends by Attribute}

People may have different needs for information on social impact depending on differences in their attitude to and knowledge of nuclear power. According to the survey examples ${ }^{5,6)}$ to find out the differences in interest in nuclear power by attribute, we can see that people have different interests in nuclear power depending on their gender, attitude to, and knowledge of, nuclear power. Also, as it has been about 40 years since the nuclear power plant was established in Fukui, the age groups of 10's to 40's, who were born after the plant establishment, and those in their 50's and older, who were born before the establishment, have different interests in nuclear power.

Therefore, we would like to understand the changes in people's needs for information on social impact depending on their age, gender, and attitude to and knowledge of nuclear power.

\section{(1) Age}

When we compare the average scores of the age groups from 10's to 40's and those of 50's and older (Table 4) before the accident, the average scores of the former age group are lower for 8 items except for "Awareness of and attitudes to nuclear power" and "Relationship with 
Table 4 Average score by age

\begin{tabular}{|c|c|c|c|c|c|c|}
\hline \multirow{2}{*}{ Gender } & \multicolumn{3}{|c|}{$10 \sim 40$ 's $(102)^{\mathrm{b})}$} & \multicolumn{3}{|c|}{50 's and older $(198)^{\mathrm{b})}$} \\
\hline & Before & After & $\begin{array}{c}\text { Difference } \\
\text { between } \\
\text { average } \\
\text { scores }\end{array}$ & Before & After & $\begin{array}{c}\text { Difference } \\
\text { between } \\
\text { average } \\
\text { scores }\end{array}$ \\
\hline $\begin{array}{l}\text { Awareness and attitudes } \\
\text { to nuclear power }\end{array}$ & 2.38 & 3.20 & $0.83^{\text {a) }}$ & 2.20 & 3.08 & $0.87^{\mathrm{a})}$ \\
\hline $\begin{array}{l}\text { Influence of harmful } \\
\text { rumors about the region }\end{array}$ & 2.07 & 3.13 & $1.06^{\mathrm{a})}$ & 2.18 & 3.08 & 0.90 \\
\hline $\begin{array}{l}\text { Relationship with the } \\
\text { power company }\end{array}$ & 2.07 & 2.77 & $0.70^{\mathrm{a})}$ & 2.07 & 2.55 & 0.47 \\
\hline $\begin{array}{l}\text { Impacts on cultural and } \\
\text { sports activities }\end{array}$ & 1.90 & 2.53 & $0.63^{\mathrm{a})}$ & 2.01 & 2.40 & 0.39 \\
\hline Changes in scenery & 2.13 & 2.82 & $0.69^{\mathrm{a})}$ & 2.19 & 2.56 & 0.36 \\
\hline $\begin{array}{l}\text { Changes in } \\
\text { infrastructure } \\
\text { development }\end{array}$ & 2.24 & 2.81 & $0.56^{\mathrm{a})}$ & 2.35 & 2.71 & 0.35 \\
\hline $\begin{array}{l}\text { Opinions about energy } \\
\text { education }\end{array}$ & 2.17 & 2.81 & $0.64^{\mathrm{a})}$ & 2.41 & 2.79 & 0.38 \\
\hline Impact on industries & 2.30 & 3.01 & $0.71^{\text {a) }}$ & 2.44 & 2.92 & 0.48 \\
\hline $\begin{array}{l}\text { Opinions about PR } \\
\text { activities }\end{array}$ & 2.00 & 2.54 & $0.54^{\text {a) }}$ & 2.26 & 2.65 & 0.39 \\
\hline $\begin{array}{l}\text { Technology } \\
\text { collaboration and } \\
\text { development }\end{array}$ & 2.16 & 2.73 & $0.57^{\mathrm{a})}$ & 2.27 & 2.69 & 0.42 \\
\hline
\end{tabular}

the power company" than the latter age group. However, after the accident, their average scores were higher for 9 items, except for "Opinions about PR activities", than the 50's and older age group. Also, for all items, the difference between average scores of the age group 10's to 40's is larger than those of all respondents collectively. In addition, when we performed a $t$-test to see whether there are differences in average scores before and after the accident, as for those aged in their 10 's to 40 's, there were significant differences at the $1 \%$ level for all items. It is assumed that although the information needs of those aged in their 10's to 40's, who were born after the plant establishment, were lower than those aged 50's and older, who were born before the establishment and before the accident, their needs increased to a greater extent than those aged 50's and older after the accident.

\section{(2) Gender}

When we compare the average scores of males and females (Table 5), the average score of females before the accident is lower than males for 9 items, but not for "Influence of harmful rumors about the region." Also, for all items, the difference between the average scores of females is larger than those of all respondents. In addition, when we performed $t$-tests to see whether there were differences in average scores before and after the accident, for females, there were significant differences at the $1 \%$ level for all items.

Females originally had low needs for information. However, it is assumed that their needs grew due to food intake restrictions after the accident, which is directly related to their lives.

\section{(3) Attitude to nuclear power}

According to the study of Shinoda ${ }^{7)}$, who found the factors that determine whether citizens 
Table 5 Average score by gender

\begin{tabular}{|c|c|c|c|c|c|c|}
\hline \multirow{2}{*}{ Gender } & \multicolumn{3}{|c|}{ Male $(158)^{\mathrm{b})}$} & \multicolumn{3}{|c|}{ Female $(135)^{\mathrm{b})}$} \\
\hline & Before & After & $\begin{array}{c}\text { Difference } \\
\text { between } \\
\text { average } \\
\text { scores }\end{array}$ & Before & After & $\begin{array}{c}\text { Difference } \\
\text { between } \\
\text { average } \\
\text { scores }\end{array}$ \\
\hline $\begin{array}{l}\text { Awareness of and } \\
\text { attitudes to nuclear } \\
\text { power }\end{array}$ & 2.32 & 3.09 & 0.77 & 2.20 & 3.18 & $0.98^{\mathrm{a})}$ \\
\hline $\begin{array}{l}\text { Influence of harmful } \\
\text { rumors about the region }\end{array}$ & 2.12 & 3.03 & 0.91 & 2.16 & 3.19 & $1.03^{\mathrm{a})}$ \\
\hline $\begin{array}{l}\text { Relationship with the } \\
\text { power company }\end{array}$ & 2.16 & 2.66 & 0.50 & 1.96 & 2.58 & $0.62^{\mathrm{a})}$ \\
\hline $\begin{array}{l}\text { Impacts on cultural and } \\
\text { sports activities }\end{array}$ & 1.97 & 2.39 & $0.41^{\mathrm{a})}$ & 1.95 & 2.50 & $0.56^{\mathrm{a})}$ \\
\hline Changes in scenery & 2.22 & 2.61 & 0.40 & 2.12 & 2.67 & $0.56^{\mathrm{a})}$ \\
\hline $\begin{array}{l}\text { Changes in } \\
\text { infrastructure } \\
\text { development }\end{array}$ & 2.41 & 2.78 & 0.38 & 2.21 & 2.68 & $0.47^{\mathrm{a})}$ \\
\hline $\begin{array}{l}\text { Opinions about energy } \\
\text { education }\end{array}$ & 2.42 & 2.80 & 0.38 & 2.19 & 2.78 & $0.59^{\mathrm{a})}$ \\
\hline Impact on industries & 2.48 & 2.93 & 0.45 & 2.28 & 2.97 & $0.69^{\mathrm{a})}$ \\
\hline $\begin{array}{l}\text { Opinions about PR } \\
\text { activities }\end{array}$ & 2.25 & 2.66 & $0.41^{\mathrm{a})}$ & 2.05 & 2.54 & $0.49^{\mathrm{a})}$ \\
\hline $\begin{array}{l}\text { Technology } \\
\text { collaboration and } \\
\text { development }\end{array}$ & 2.35 & 2.75 & 0.40 & 2.09 & 2.64 & $0.56^{\mathrm{a})}$ \\
\hline
\end{tabular}

are for or against the use of nuclear power, we can well understand the situation where nuclear power is placed by dividing a group of people who negatively agree with the use of nuclear power into two groups: people who are rather for and who are rather against nuclear power use. Thus, for the attitudes to nuclear power, we cannot divide people into just two groups, with one for and the other against. Therefore, we provided five multiple-choice options (1. should definitely develop and use, 2. should develop and use until alternative energy is fully available, 3 . should maintain the status quo, 4 . should discontinue use in a phased manner, and 5. Should discontinue immediately) for the question concerning attitude to nuclear power use, and allowing for multiple answers. Then, we divided the respondents into three groups: people who accept nuclear power at this stage, people who oppose nuclear power at this stage, and people who suspend judgment because they may change their attitude depending on the future energy situation. The first option clearly shows the acceptance of nuclear energy at this stage. Therefore, we categorized those who solely chose the first option, and those who chose the first plus other options, as the Acceptance Group. Then, the fifth option clearly shows opposition to nuclear power at this stage, so we categorized those who solely chose the fifth option, and those who chose the fifth and other options as the Opposition Group. Although option 4 also shows opposition, those who chose this option can be categorized into the Acceptance Group and Suspended Attitude Group depending on what other options they chose. Therefore, we categorized those who solely chose option 4 as the Opposition Group and categorized those who chose option 4 plus other options into a group that also reflected the other options they chose. Option 3 is an option that clearly shows respondents' suspended attitude. Therefore, we categorized the respondents who solely chose the third option and chose the third and other 
Table 6 Categories of attitude to nuclear power

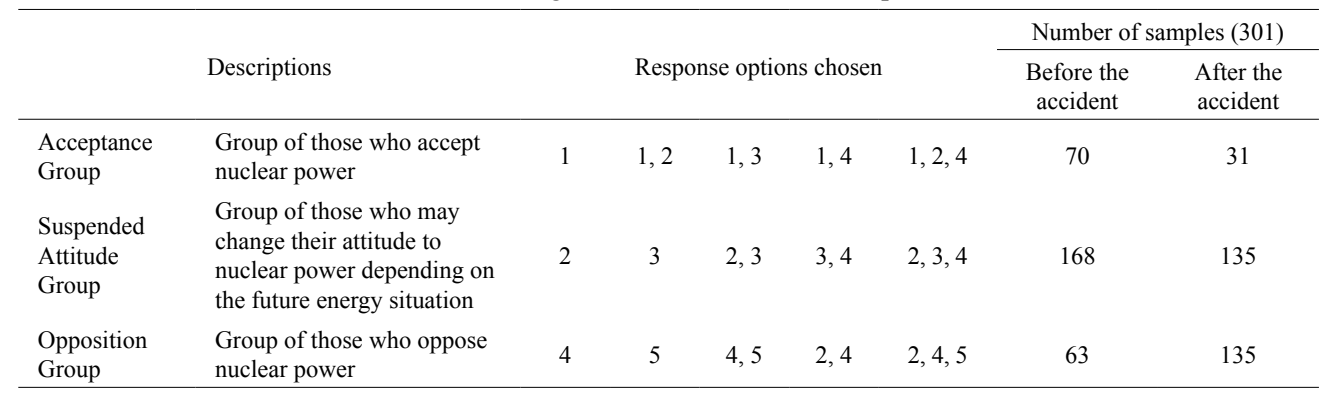

1: Should definitely develop and use; 2 : Should develop and use until alternative energy is fully available; 3 : Should maintain the status quo; 4: Should discontinue in a phased manner; 5: Should discontinue immediately

options as the Suspended Attitude Group. Those who chose option 2 can be categorized into both the Acceptance Group and the Opposition Group. We determined their group depending on what other options they chose. Table 6 shows the categorizing method.

To verify the validity of the classifications, we performed an analysis of variance for the average scores of each of the three groups on each item and examined whether there were differences between groups. We found significant differences at the 5\% level for the following four items: "Awareness of and attitudes to nuclear power," "Impacts on cultural and sports activities," "Opinions about energy education," and "Technology collaboration and development"; there were significant differences at the $1 \%$ level in the following three items: "Influence of harmful rumors about the region," "Relationship with the power company," and "Opinions about PR activities." No difference was observed in the following three items: "Changes in scenery," "Changes in infrastructure development," and "Impact on industries." Then, we compared the average scores between three groups for the 7 items, where significant differences were observed at $1 \%$ and $5 \%$ levels.

The average score results are shown in Table 7. When we compare each group, the average score of the first group (acceptance) was high for all seven items before the accident. However, after the accident, the average scores of "Awareness of and attitudes to nuclear power" and "Influence of harmful rumors about the region" are high for all groups (Acceptance/Suspended Attitude/Opposition). Differences between the average scores of the Suspended Attitude Group are higher than those of all the other respondents for all seven items. Also, a $t$-test on the differences of the average scores before and after the accident showed that the Suspended Attitude Group displayed significant differences at the $1 \%$ level for all items. The information needs of the Acceptance Group have been high since before the accident and the needs of the Suspended Attitude Group increased after the accident.

\section{(4) Knowledge of nuclear power}

The respondents were asked to respond to the questions on their knowledge of nuclear power from four multiple-choice answers: "I know a lot," "I know a little," "I don't know very much," and "I don't know anything." We considered those who answered either "I know a lot" or "I know a little" to be a group with relatively high knowledge and those who answered either "I don't know very much" and "I don't know anything" to be a group with relatively less knowledge.

When we compared the respondents' knowledge of nuclear power before and after the accident (Figure 3), we found that before the accident, the group with relatively high knowledge was less than half of all respondents at $44 \%$ but was more than half at $57 \%$ after the accident. 
Table 7 Average scores by attitude toward nuclear power

\begin{tabular}{|c|c|c|c|c|c|c|c|c|c|}
\hline \multirow[b]{2}{*}{ Item } & \multicolumn{3}{|c|}{ Acceptance } & \multicolumn{3}{|c|}{ Suspended } & \multicolumn{3}{|c|}{ Opposition } \\
\hline & $\begin{array}{l}\text { Before } \\
(70)^{\mathrm{c})}\end{array}$ & $\begin{array}{l}\text { After } \\
(31)^{c)}\end{array}$ & $\begin{array}{c}\text { Difference } \\
\text { between } \\
\text { average } \\
\text { scores }\end{array}$ & $\begin{array}{l}\text { Before } \\
(168)^{c)}\end{array}$ & $\begin{array}{l}\text { After } \\
(135)^{\mathrm{c})}\end{array}$ & $\begin{array}{c}\text { Difference } \\
\text { between } \\
\text { average } \\
\text { scores }\end{array}$ & $\begin{array}{l}\text { Before } \\
(63)^{c)}\end{array}$ & $\begin{array}{l}\text { After } \\
(135)^{\mathrm{c})}\end{array}$ & $\begin{array}{c}\text { Difference } \\
\text { between } \\
\text { average } \\
\text { scores }\end{array}$ \\
\hline $\begin{array}{l}\text { Awareness of and } \\
\text { attitudes to nuclear } \\
\text { power }\end{array}$ & 2.47 & 3.06 & 0.59 & 2.14 & 3.15 & $1.01^{\mathrm{a})}$ & 2.35 & 3.10 & 0.75 \\
\hline $\begin{array}{l}\text { Influence of harmful } \\
\text { rumors about the } \\
\text { region }\end{array}$ & 2.40 & 3.06 & 0.66 & 1.96 & 3.07 & $1.10^{\mathrm{a})}$ & 2.33 & 3.13 & 0.80 \\
\hline $\begin{array}{l}\text { Relationship with the } \\
\text { power company }\end{array}$ & 2.39 & 2.90 & $0.52^{\mathrm{b})}$ & 1.91 & 2.65 & $0.74^{\text {a) }}$ & 2.14 & 2.53 & 0.38 \\
\hline $\begin{array}{l}\text { Impacts on cultural } \\
\text { and sports activities }\end{array}$ & 2.19 & 2.68 & $0.49^{\mathrm{b})}$ & 1.89 & 2.52 & $0.63^{\mathrm{a})}$ & 1.97 & 2.32 & 0.35 \\
\hline Changes in scenery & 2.36 & 2.81 & $0.45^{\mathrm{b})}$ & 2.12 & 2.65 & $0.53^{\text {a) }}$ & 2.10 & 2.60 & $0.50^{\mathrm{a})}$ \\
\hline $\begin{array}{l}\text { Changes in } \\
\text { infrastructure } \\
\text { development }\end{array}$ & 2.51 & 2.77 & 0.26 & 2.28 & 2.88 & $0.60^{\mathrm{a})}$ & 2.19 & 2.59 & $0.40^{\mathrm{a})}$ \\
\hline $\begin{array}{l}\text { Opinions about } \\
\text { energy education }\end{array}$ & 2.59 & 3.00 & 0.41 & 2.25 & 2.83 & $0.58^{\text {a) }}$ & 2.24 & 2.72 & 0.48 \\
\hline Impacts on industries & 2.63 & 3.06 & 0.44 & 2.33 & 3.01 & $0.68^{a)}$ & 2.29 & 2.86 & 0.57 \\
\hline $\begin{array}{l}\text { Opinions about PR } \\
\text { activities }\end{array}$ & 2.44 & 2.97 & $0.52^{\mathrm{a})}$ & 2.03 & 2.67 & $0.64^{\text {a) }}$ & 2.24 & 2.47 & 0.24 \\
\hline $\begin{array}{l}\text { Technology } \\
\text { collaboration and } \\
\text { development }\end{array}$ & 2.49 & 2.97 & 0.48 & 2.14 & 2.84 & $0.69^{a)}$ & 2.19 & 2.51 & 0.32 \\
\hline
\end{tabular}

a) The numbers indicate scores larger than the difference of average scores and are significant at the $1 \%$ level using a $t$-test.

b) The numbers indicate scores larger than the difference of average scores and are significant at the $5 \%$ level using a $t$-test.

c) The numbers in brackets indicate the number of samples.

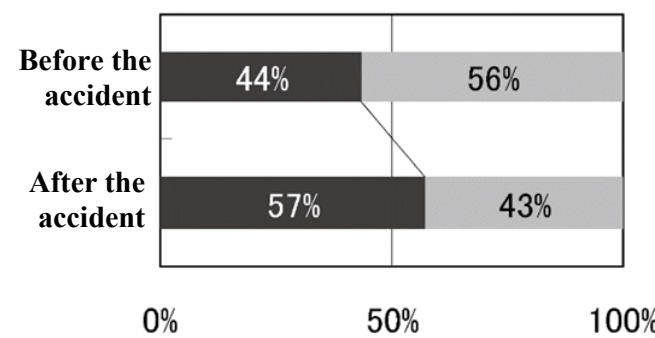

Group with relatively high knowledge

Group with relatively less knowledge

Figure 3 Comparison of knowledge of nuclear power before and after the accident

Respondents' knowledge of nuclear power increased after the accident.

Next, when we compared the average scores of the group with relatively high knowledge and the group with relatively less knowledge (Table 8), the average scores of the group with high knowledge were higher before and after the accident and their information needs had been high since before the accident. However, after the accident, the average scores of the group with relatively less knowledge increased more than the average score of all the respondents for all items. In addition, when we performed a $t$-test to see whether there were differences in average scores before and after the accident, for the group with relatively less knowledge, differences 
Table 8 Average scores by group (from the perspective of knowledge of nuclear power) on nuclear power

\begin{tabular}{|c|c|c|c|c|c|c|}
\hline \multirow[b]{2}{*}{ Item } & \multicolumn{3}{|c|}{ Group that has more knowledge } & \multicolumn{3}{|c|}{ Group that has less knowledge } \\
\hline & $\begin{array}{l}\text { Before } \\
(131)^{\text {b) }}\end{array}$ & $\begin{array}{l}\text { After } \\
(172)^{\text {b) }}\end{array}$ & $\begin{array}{c}\text { Difference } \\
\text { between } \\
\text { average } \\
\text { scores }\end{array}$ & $\begin{array}{l}\text { Before } \\
(170)^{\text {b) }}\end{array}$ & $\begin{array}{l}\text { After } \\
(129)^{\text {b) }}\end{array}$ & $\begin{array}{c}\text { Difference } \\
\text { between } \\
\text { average } \\
\text { scores }\end{array}$ \\
\hline $\begin{array}{l}\text { Awareness of and } \\
\text { attitudes to nuclear } \\
\text { power }\end{array}$ & 2.46 & 3.09 & 0.63 & 2.11 & 3.16 & $1.05^{\mathrm{a})}$ \\
\hline $\begin{array}{l}\text { Influence of harmful } \\
\text { rumors about the region }\end{array}$ & 2.34 & 3.05 & 0.71 & 1.99 & 3.16 & $1.17^{\mathrm{a})}$ \\
\hline $\begin{array}{l}\text { Relationship with the } \\
\text { power company }\end{array}$ & 2.31 & 2.61 & 0.30 & 1.88 & 2.64 & $0.75^{\mathrm{a})}$ \\
\hline $\begin{array}{l}\text { Impacts on cultural and } \\
\text { sports activities }\end{array}$ & 2.15 & 2.44 & 0.30 & 1.84 & 2.45 & $0.61^{\mathrm{a})}$ \\
\hline Changes in scenery & 2.37 & 2.76 & 0.38 & 2.01 & 2.50 & $0.48^{\text {a) }}$ \\
\hline $\begin{array}{l}\text { Changes in } \\
\text { infrastructure } \\
\text { development }\end{array}$ & 2.50 & 2.77 & 0.28 & 2.18 & 2.70 & $0.52^{\mathrm{a})}$ \\
\hline $\begin{array}{l}\text { Opinions about energy } \\
\text { education }\end{array}$ & 2.59 & 2.85 & 0.26 & 2.12 & 2.73 & $0.61^{\text {a) }}$ \\
\hline Impact on industries & 2.65 & 2.99 & 0.34 & 2.19 & 2.90 & $0.71^{\mathrm{a})}$ \\
\hline $\begin{array}{l}\text { Opinions about PR } \\
\text { activities }\end{array}$ & 2.38 & 2.65 & 0.26 & 2.01 & 2.57 & $0.56^{\mathrm{a})}$ \\
\hline $\begin{array}{l}\text { Technology } \\
\text { collaboration and } \\
\text { development }\end{array}$ & 2.48 & 2.74 & 0.26 & 2.04 & 2.66 & $0.62^{\mathrm{a})}$ \\
\hline
\end{tabular}

a) The numbers indicate scores larger than the difference of the average scores of all the respondents and are significant at the $1 \%$ level using a $t$-test.

b) The numbers in brackets indicate the number of samples.

were significant at the $1 \%$ level for all items.

As the information needs of the group with less knowledge increased after the accident, and there were no significant differences between their average scores and those of the group with relatively high knowledge, we can assume that the information needs increased regardless how much knowledge people had originally.

\section{Detailed Analysis of Items with High Information Needs}

Based on the analysis so far, as the average scores for "Awareness of and attitudes to nuclear power," "Influence of harmful rumors about the region," and "Impacts on industries" were high after the accident, they are assumed to have high information needs (Table 3). However, from only the names of the items, it is unknown what particular information people are interested in. Therefore, in this section, we would like to clarify the three items in greater detail.

In this survey, we provided free-answer fields to gain information on what they wanted to hear regarding each item. Then, using the free answers, we categorized and conducted analysis on information they wanted regarding "Awareness of and attitudes to nuclear power," "Influence of harmful rumors about the region," and "Impact on industries." Their free answers are provided in Table 9. Answers containing several questions were categorized across several items. Also, respondents' provided opinions that were not questions they would like to ask the 
Table 9 Free answers

\begin{tabular}{|c|c|c|c|}
\hline Item & Contents of free answers & $\begin{array}{l}\text { \# of respondents } \\
\text { who provided } \\
\text { free answers }\end{array}$ & $\begin{array}{l}\text { \# of free } \\
\text { answers }\end{array}$ \\
\hline $\begin{array}{l}\text { Awareness of and } \\
\text { attitudes to nuclear } \\
\text { power }\end{array}$ & $\begin{array}{l}\text { Awareness of potential hazards and safety/For or against the } \\
\text { acceptance of nuclear power/Changes in awareness/attitudes after the } \\
\text { accident/Local growth strategies and employment/Safety measures/ } \\
\text { Accident and evacuation coverage/Anxiety/Balance between risks } \\
\text { and benefits/Radiation effects/Feeling when accepting/Real feeling/ } \\
\text { Emotional distress/Demand/Others/Opinion }\end{array}$ & 88 & 106 \\
\hline $\begin{array}{l}\text { Influence of harmful } \\
\text { rumors about the } \\
\text { region }\end{array}$ & $\begin{array}{l}\text { Impacts on lives/Measures/Residents' opinion/Actual harm of } \\
\text { radiation/Balance between risks and benefits/Impacts on agriculture } \\
\text { and fishery/Influence of harmful rumors in mass media/Termination } \\
\text { period/Influence on areas where no accident occurred/Impact on } \\
\text { tourism industry/For or against the acceptance of nuclear power/ } \\
\text { Others/Opinion }\end{array}$ & 59 & 63 \\
\hline $\begin{array}{l}\text { Relationship with } \\
\text { the power company }\end{array}$ & $\begin{array}{l}\text { PR Methods/Positions of those who interact with/Details of } \\
\text { interactions/Opinions of nuclear-related businesses/Opportunity to } \\
\text { interact (frequency and period)/Contribution to the region/Others/ } \\
\text { Opinion }\end{array}$ & 47 & 47 \\
\hline $\begin{array}{l}\text { Impacts on cultural } \\
\text { and sports activities }\end{array}$ & $\begin{array}{l}\text { Effects and contributions/Activity details/Funds/Continuity/Others/ } \\
\text { Opinion }\end{array}$ & 27 & 32 \\
\hline Changes in scenery & $\begin{array}{l}\text { Scenic attraction/Protection and destruction of nature/Impact on } \\
\text { tourism industry/Others/Opinion }\end{array}$ & 36 & 38 \\
\hline $\begin{array}{l}\text { Changes in } \\
\text { infrastructure } \\
\text { development }\end{array}$ & $\begin{array}{l}\text { Financial perspective/Balance between risks and benefits/ } \\
\text { Evacuation road/Demand for the maintenance of roads and facilities/ } \\
\text { Convenience/Others/Opinion }\end{array}$ & 47 & 50 \\
\hline $\begin{array}{l}\text { Opinions about } \\
\text { energy education }\end{array}$ & $\begin{array}{l}\text { Education details/Human resource development/Current status of } \\
\text { energy supply/Research details/Others/Opinion }\end{array}$ & 54 & 54 \\
\hline Impact on industries & $\begin{array}{l}\text { Positive and negative perspectives/Employment/R\&D and technical } \\
\text { collaborations/Ties with industries/Balance between risks and } \\
\text { benefits/Human resource development/Tax revenue/Others/Opinion }\end{array}$ & 50 & 53 \\
\hline $\begin{array}{l}\text { Opinions about PR } \\
\text { activities }\end{array}$ & $\begin{array}{l}\text { Bias of PR content/Safety measures/Reliability of PR contents/ } \\
\text { Necessary information/Others/Opinion }\end{array}$ & 47 & 49 \\
\hline $\begin{array}{l}\text { Technology } \\
\text { collaboration and } \\
\text { development }\end{array}$ & $\begin{array}{l}\text { Benefits/Balance between risks and benefits/Human resource } \\
\text { development/Safety measures/Anxiety/Others/Opinion }\end{array}$ & 37 & 40 \\
\hline
\end{tabular}

local residents, were categorized as "Opinion." c The content of free answers, their description examples, and the number of free answers of "Awareness and attitudes to nuclear power," "Influence of harmful rumors about the region," and "Impact on industries" are provided in Tables 10 to 12.

When we look at respondents' free answers for "Awareness of and attitudes to nuclear power," we found questions raised about "Awareness of potential hazards and safety," "For or against the acceptance of nuclear power," and "Changes in awareness after the accident," and they focus on how the local residents perceived risks and safety measures in regard to nuclear power and how these perceptions changed after the accident.

As for "Influence of harmful rumors about the region," questions were raised about the course of improvement such as "Measures," "Termination period," "Balance between risks and benefits," and "Impact on lives," and they tend to show high interest in measures to counter harmful rumors about the region and the actual current status.

When we look at free answers for "Impact on industries," questions such as "Positive and negative perspectives," "Employment," and "Balance between risks and benefits" are raised

\footnotetext{
${ }^{\mathrm{c}}$ Research associates and students who major in nuclear power (2 students in secondary doctoral course and 2 students in primary doctoral course) categorized respondents into the set categories, which was regarded as the final decision.
} 
Table 10 Free answers by attribute for awareness/attitudes to nuclear power

\begin{tabular}{|c|c|c|}
\hline Content of free answers & Answer examples & $\begin{array}{l}\# \text { of free } \\
\text { answers }\end{array}$ \\
\hline $\begin{array}{l}\text { Awareness of and attitudes } \\
\text { to potential hazards and } \\
\text { safety }\end{array}$ & $\begin{array}{l}\text { How much do local residents hear about safety and what is the level of their } \\
\text { understanding? How much do local residents want to know about the risks } \\
\text { associated with nuclear power? }\end{array}$ & 13 \\
\hline $\begin{array}{l}\text { For or against the } \\
\text { acceptance of nuclear } \\
\text { power }\end{array}$ & Do we need nuclear power or not? Are we able to live with nuclear power? & 12 \\
\hline $\begin{array}{l}\text { Changes in awareness after } \\
\text { the accident }\end{array}$ & $\begin{array}{l}\text { Feeling of local residents regarding the collapse of safety myth due to the } \\
\text { accident/I would like to know what the local residents think about disasters } \\
\text { such as the Great Eastern Japan Earthquake }\end{array}$ & 12 \\
\hline $\begin{array}{l}\text { Local growth strategies and } \\
\text { employment }\end{array}$ & $\begin{array}{l}\text { Does a nuclear power plant provide job opportunities? Aren't there any (work- } \\
\text { related) safety issues? }\end{array}$ & 11 \\
\hline Safety measures & $\begin{array}{l}\text { Are measures established to deal with nuclear power-related problems when } \\
\text { they occur? }\end{array}$ & 6 \\
\hline $\begin{array}{l}\text { Accident and evacuation } \\
\text { coverage }\end{array}$ & What coverage do residents wish when an evacuation order is issued? & 6 \\
\hline Anxiety & $\begin{array}{l}\text { What are residents' feelings and concerns about the safety and security of } \\
\text { living in the region? }\end{array}$ & 6 \\
\hline $\begin{array}{l}\text { Balance between risks and } \\
\text { benefits }\end{array}$ & $\begin{array}{l}\text { What are the residents' views on (a) benefits including improvement of } \\
\text { local economy in the area where nuclear power plant is located and (b) } \\
\text { improvement of infrastructure and disadvantages including harmful effects if } \\
\text { a nuclear accident occurred? }\end{array}$ & 4 \\
\hline Radiation effects & Are there more or less some sort of health-related changes? & 4 \\
\hline Feeling when accepting & How did residents start accepting nuclear power? & 3 \\
\hline Real feeling & I would like to know the true opinions of local residents. & 3 \\
\hline Emotional distress & $\begin{array}{l}\text { Are there any people who oppose the establishment of a nuclear power plant? } \\
\text { If you are opposed, will it be hard to live in the area? }\end{array}$ & 2 \\
\hline Demand & $\begin{array}{l}\text { Demands to the government and nuclear power plant from safety and security } \\
\text { perspectives }\end{array}$ & 2 \\
\hline Others & $\begin{array}{l}\text { Differences between reported information and actual information, changes in } \\
\text { the future visions due to nuclear power plant siting }\end{array}$ & 5 \\
\hline Opinion & $\begin{array}{l}\text { Anxiety about safety, lack of residents' knowledge of nuclear power, and } \\
\text { reluctance of residents to express their opinions }\end{array}$ & 17 \\
\hline Total & & 106 \\
\hline
\end{tabular}

* Actual free answers are provided except those in the categories of "Others" and "Opinion." (Some changes are applied to the extent that such changes do not change the meaning.)

and respondents are interested in the economic benefits and disadvantages of plant siting.

Also, for all of the following items, "Awareness of and attitudes to nuclear power," "Influence of harmful rumors about the region," and "Impact on industries," respondents provide not questions but opinions and thoughts relevant to the examples of the social impact items. This shows that respondents want specific information on social impacts rather than the current situations in the power plant siting area.

\section{Conclusions}

Comparing the need for information on social impacts due to nuclear power plant siting before and after the accident, information needs have increased for three items: "Awareness of and attitudes to nuclear power," "Influence of harmful rumors about the region," and "Impact on industries" after the accident. The need for information on social impacts increased after the accident among those aged in their 10 's to 40 's, who were born after the power plant 
Table 11 Free answers by attribute for the influence of harmful rumors about the region

\begin{tabular}{|c|c|c|}
\hline Contents of free answers & Examples & $\begin{array}{l}\text { \# of free } \\
\text { answers }\end{array}$ \\
\hline Impacts on lives & $\begin{array}{l}\text { I would like to know how harmful rumors can change residents' lives/How } \\
\text { they actually change their life. }\end{array}$ & 7 \\
\hline Measures & $\begin{array}{l}\text { What measures did the government and mass media take for harmful rumors? } \\
\text { What measures do residents want for harmful rumors? }\end{array}$ & 6 \\
\hline Residents' opinion & $\begin{array}{l}\text { I would like to know the current feeling of neighboring residents/I would like } \\
\text { to know what they think about harmful rumors. }\end{array}$ & 6 \\
\hline Actual harm of radiation & $\begin{array}{l}\text { Effect on body/It's been } 40 \text { years since the power plant was built, and I wonder } \\
\text { if there has been any leakage of radiation or any problems with the ocean } \\
\text { environment. }\end{array}$ & 4 \\
\hline $\begin{array}{l}\text { Balance between risks and } \\
\text { benefits }\end{array}$ & $\begin{array}{l}\text { Do the residents live there because they believe they have benefits even } \\
\text { though harmful rumors can have some impacts? }\end{array}$ & 3 \\
\hline $\begin{array}{l}\text { Impacts on agriculture and } \\
\text { fishery }\end{array}$ & $\begin{array}{l}\text { We didn't think having a nuclear power plant was dangerous before the } \\
\text { accident, but we are worried about contamination in agriculture and fishery } \\
\text { ecosystems. }\end{array}$ & 3 \\
\hline Impact on tourism industry & Impacts on tourists/Impacts on Minshuku and accommodation businesses & 2 \\
\hline $\begin{array}{l}\text { Influence of harmful } \\
\text { rumors in mass media }\end{array}$ & $\begin{array}{l}\text { Specific details of harmful rumors in mass media and the extent of effects on } \\
\text { the region from harmful rumors }\end{array}$ & 2 \\
\hline Termination period & How long did it take before harmful rumors disappeared? & 2 \\
\hline $\begin{array}{l}\text { Influence on areas where } \\
\text { no accident occurs }\end{array}$ & $\begin{array}{l}\text { Are there harmful rumors even in areas where nuclear power plants are located } \\
\text { but no nuclear accidents have occurred? }\end{array}$ & 2 \\
\hline $\begin{array}{l}\text { For or against the } \\
\text { acceptance of nuclear } \\
\text { power }\end{array}$ & $\begin{array}{l}\text { Do residents think they can live with nuclear power even after such a } \\
\text { disastrous accident? }\end{array}$ & 3 \\
\hline Others & Influence on terrorism, information reliability, government's opinions, etc. & 5 \\
\hline Opinion & $\begin{array}{l}\text { Inevitability of harmful rumors, insufficient information disclosure, anxiety, } \\
\text { etc. }\end{array}$ & 18 \\
\hline Total & & 63 \\
\hline
\end{tabular}

* Actual free answers are provided except those in the categories of "Others" and "Opinion." (Some changes are applied to the extent that such changes do not change the meaning.)

establishment, in females, who seem to be less interested in nuclear power, in the Suspended Attitude Group, which consists of people who do not clearly show their attitude to nuclear power, and in the group with relatively less knowledge about nuclear power.

At the end of the survey, we categorized and analyzed questions given to local residents about "Awareness of and attitudes to nuclear power," "Influence of harmful rumors about the region," and "Impact on industries" using free answer questions. The results showed that respondents are interested in economic impacts such as regional development projects and employment due to the nuclear power plant siting, they also revealed residents' subjective opinions about risks of nuclear power, and the need for information on the economic and mental benefits and disadvantages related to the power plant siting.

We assumed that those who had never clearly revealed their attitudes to nuclear power and those with no knowledge of or interest in nuclear power may not be particularly interested in information on social impacts as well as in information on nuclear power in general. However, now that we have confirmed the information needs of these groups, we believe it is useful to distribute this information on social impacts to the group whose interest has increased after the accident so that they will recognize the social impact and be motivated to become interested in nuclear power. However, since respondents did not register an opinion in the free answer field in many cases, there is a gap between what residents want to hear and the information provided in this leaflet; we still have a little more work to do on the information that needs to be provided. Also, we found that residents are interested in specific information on social impacts 
Table 12 Free answers by attribute for impact on industries

\begin{tabular}{|c|c|c|}
\hline Free answers & Examples & $\begin{array}{l}\text { \# of free } \\
\text { answers }\end{array}$ \\
\hline $\begin{array}{l}\text { Positive and negative } \\
\text { perspectives }\end{array}$ & $\begin{array}{l}\text { The region has accrued benefits in various ways, but I wonder if everyone has } \\
\text { been the beneficiary of such benefits. I wonder if the residents are forced to } \\
\text { put up with many things in return/I wonder how much benefit the region has } \\
\text { received and whether residents can actually feel any benefit. }\end{array}$ & 10 \\
\hline Employment & $\begin{array}{l}\text { I wonder to what extent nuclear-related employment opportunities have been } \\
\text { created for neighboring residents. }\end{array}$ & 5 \\
\hline $\begin{array}{l}\text { R\&D and technical } \\
\text { collaborations }\end{array}$ & $\begin{array}{l}\text { I wonder whether we can expect development in other industries such as } \\
\text { medical and bio technologies. }\end{array}$ & 3 \\
\hline Ties with industries & $\begin{array}{l}\text { I would like to know what percentage of businesses in Fukui Prefecture are } \\
\text { related to the nuclear plant. }\end{array}$ & 3 \\
\hline $\begin{array}{l}\text { Balance between risks and } \\
\text { benefits }\end{array}$ & $\begin{array}{l}\text { I wonder if the government thinks they should retain the employment } \\
\text { opportunities and economic effects in exchange for accepting the risks } \\
\text { associated with nuclear power. }\end{array}$ & 3 \\
\hline $\begin{array}{l}\text { Human resource } \\
\text { development }\end{array}$ & Current state of human resource development & 2 \\
\hline Tax revenue & Impact on the local government in terms of tax-related matters & 2 \\
\hline Others & $\begin{array}{l}\text { Impacts on agriculture and fishery, impact of accident/How to develop } \\
\text { industries independent of nuclear power. }\end{array}$ & 13 \\
\hline Opinion & $\begin{array}{l}\text { Economic revitalization utilizing nuclear industry, regional economic decline } \\
\text { due to the power plant siting }\end{array}$ & 12 \\
\hline Total & & 53 \\
\hline
\end{tabular}

* Actual free answers are provided except those in the categories of "Others" and "Opinion." (Some changes are applied to the extent that such changes do not change the meaning.)

rather than the current status of the area where the power plant is located. To utilize information on social impacts, we need to provide not only the information people need to affirm or revise their opinions, and history of nuclear power plant siting, but also to study just what information to deliver, and how that information should be delivered to offer future prospect, and how to enable people to think about the region in a comprehensive manner and carry out plans to provide information appropriately.

\section{References}

1) H. Kimura, C. Katsuki, H. Madarame, T. Miyazawa, Study on "Facilitation Forum" for Nuclear Energy with Social and Technological Knowledge Circulation, NV Laboratory, Feb. 2008. [in Japanese]

2) Y. Tada, C. Hayashi, "A survey study about what an exhibition hall of nuclear power station should be," INSS J., 8, 15-26 (2004). [in Japanese]

3) Y. Shinoda, H. Torii, N. Yamano, Heisei 19 Nendo Oarai Fieldwork Cyosahokokusho, Tokyo Institute of Technology, Feb. 2 (2008). [in Japanese]

4) Heisei 22 Nendo, Genshiryokuriyo no Chishiki Fukyu Keihatsu ni Kansuru Yoronchosa, Japan Atomic Energy Relations Organization, Feb. (2010). [in Japanese]

5) N. Tsujikawa, S. Tsuchida, T. Shiotani, "Effects of perceptions of the necessities and anxieties associated with nuclear power on motivation for considering nuclear power generation," Shakai-gijutu Kenkyu Ronbunshu, 8, 74-81 (2011). [in Japanese]

6) Heisei 19, Nendo Enerugi ni Kansuru Koshu no Ishikichosa Hokokushu, The Institute of Applied Energy, Mar. (2008). [in Japanese]

7) Y. Shinoda, "Consideration on the interaction between society and nuclear technology," Trans. At. Energy Soc. Jpn., 6 [2], 97-112 (2007). [in Japanese] 